DOI https://doi.org/10.36059/978-966-397-225-1-12

\title{
FOLK DANCE THEATRICAL ADAPTATION
}

\section{Boiko Olha}

\section{INTRODUCTION}

The concept of "theatrical adaptation" at the beginning of the 21 st century, due to its active use in Art Studies, is seen as one of the fundamental categories, ignoring of which eliminates the possibility of thorough and comprehensive research and understanding of the processes in contemporary art.

The study of the theatrical adaptation techniques is significant referring the choreology, as choreography and theatre are based on shared principles of playful conventionality, and their interaction is enhanced in the moments of searching for specific individual features of choreographic art.

Ukrainian folk dances are a unique artistic and figurative sign system, full of exceptional metaphorical imagery. National dance folklore is characterised by a rich history, stable traditions, bright temperament and imagery, original vocabulary and performance techniques, as well as a significant variety of plastic forms and numerous elements of theatricality. At the present stage of development of society, its successor is the Ukrainian stage folk dance that was formed in the 20th century; it embodies the unique national choreographic art. Now there is a need to explore theatrical adaptation as one of the trends in the development of Ukrainian staged folk dance of the 21 st century.

The scientific novelty is in the implementation of a comparative analysis of the characteristics of theatrical adaptation as a trend in the development of national professional choreographic art in general and staged folk dance in particular in the late 19th - early 20th century and at the present stage.

The influence of a specific sociocultural context on the process of theatrical adaptation, as well as the most popular and effective formats of representation of Ukrainian folk dance on the stage, are revealed.

The analysis of publications indicates that modern Ukrainian choreographic culture as a complex and multifaceted phenomenon is of constant interest in the scientific dimension of the 21st century. The development issue of staged folk choreography in Ukraine has been studied 
quite actively in recent years. Mind V. Nechytailo's ${ }^{1}$ scientific publications, in which the researcher reveals the importance of national folk choreographic art in the process of formation of national and cultural values; L. Khotsianovska's ${ }^{2}$ studies; and I. Hutnyk ${ }^{3}$, in which the author explores the peculiarities of the implementation of stylisation of folk dance as a prevalent direction of the 21 st century, trying to determine its place and role in the context of professional choreographic art.

However, paying attention to the dynamism of the transformation processes of sociocultural space due to the general vector of development of world culture, the specifics and trends of Ukrainian staged folk dance in the early 2020 s are studied insufficiently, that actualises researches in this direction.

The purpose of the study is to identify the specifics of theatrical adaptation as a trend in the development of Ukrainian staged folk choreography in historical retrospect and at the present stage.

\section{Folklore and Staged Folk Dance in Terms of Theatrical Adaptation}

Folk dance has been an essential part of the life of people since ancient times, and therefore an important part of the intangible cultural heritage, directly related to local culture and ethnic or another group identity ${ }^{4}$. The "active" cultural elements, which are present at many levels of folk dance, are significant for the integrity of a person's identity in the energetic rhythms of modern society development. The cultural code that should be passed on to the next generation is directly related to the various folk dance practices that are passed down personally and studied by imitation of movements. Modern forms of folk dance distribution, which adapt them to the changing dynamics of the dance culture evolution, are of great importance.

1 Nechytailo V. S. (2017) Narodne khoreohrafichne mystetstvo Ukrainy u sotsiokulturnykh umovakh sohodennia [Folk choreographic art of Ukraine in the modern socio-cultural condition]. National Academy of Managerial Staff of Culture and Arts Herald, no. 2, pp. 88-93.

2 Khotsianovska L. F. (2018) Tendentsii ta perspektyvy rozvytku narodnoho khoreohrafichnoho mystetstva Ukrainy [Trends and prospects of the development of folk choreographic art of Ukraine]. Young Scientist, no. 1(53), pp. 191-194.

${ }^{3}$ Hutnyk I. M. (2019) Stylizatsiia u profesiinomu narodnomu khoreohrafichnomu mystetstvi suchasnosti [Styling in professional folk choreographic art of the present]. National Academy of Managerial Staff of Culture and Arts Herald, no. 2, pp. 356-360.

${ }^{4}$ Protopapadakis E., Grammatikopoulou A., Doulamis A., Grammalidis N. (2017) Folk Dance Pattern Recognition over Depth Images Acquired via Kinect Sensor. The International Archives of the Photogrammetry, Remote Sensing and Spatial Information Sciences, vol. XLII-2/W3, p. 589. 
Theatrical adaptation as a sociocultural phenomenon acquires particular relevance in the 21st century, due to the formation of a new type of thinking as a trend of modern society and the readiness of culture to further promotion of aesthetic potential. In particular, the interest in the theatricalised perception of any information increases significantly.

The purpose of theatrical adaptation is to adapt any material for stage embodiment by specific expressive means inherent to the theatre.

We see the concept of "theatrical adaptation" in the context of the topic of this study as a process of providing Ukrainian folklore dance (as a work of folk culture), which isn't related to the theatrical interpretation, game and role features; stage interpretation of a piece of dance folklore or its elements, which can occur at the dramatic level and the level of visual translation of images.

According to the specifics of historical development, theatrical adaptation and stylisation of Ukrainian folk dance through its technical complexity and free stage interpretation become one of the leading trends in the formation of national professional choreography in the late 19th - early 20th century. The direction of technical complication of folk dance and academic theatrical adaptation was developed by M. Sobol, H. Khotkevych, V. Avramenko and other leading choreographers according to their vision of this process.

M. Sobol, a Kh. Nizhynskyi's student, created experimental, innovative constructions (vertical, horizontal lines, stars, circles, and gates), compositions, and theatricalised suites. K. Vasylenko ${ }^{5}$ emphasises that to reveal the theme and plot of a stage production, M. Sobol focused on the combination of the main structure of folk dance movements with classical dance techniques, as a result of which the choreographic vocabulary became much more complicated and innovative forms of such traditional movements as "squat", "slide", etc. were formed. But H. Khotkevych considered a theatrical adaptation of folk dance as a combination of authentic folklore and dramatic art in the Hutsul Theatre founded by him in 1910; the performers were folklore dancers only ${ }^{6}$.

Studying V. Avramenko's work, national scholars emphasise the choreographer's interpretation of the original folklore source and the

5 Vasylenko K. Yu. (1996) Leksyka ukrainskoho narodno-stsenichnoho tantsiu [Vocabulary of Ukrainian folk stage dance]. Kyiv: Mystetstvo, p. 114.

${ }^{6}$ Shlemko O. (2002) Arkhaichni narodni tradytsii v interpretatsii Hutsulskoho teatru Hnata Khotkevycha [Archaic folk traditions in the interpretation of the Hutsul Hnat Khotkevych Theater]. Proceedings of the Tradytsiia $i$ suchasne $v$ ukrainskii kulturi: Mizhnarodna naukovo-praktychna konferentsiia (Ukraine, Kharkiv, December 18-21, 2002). Kharkiv: National Technical University «Kharkiv Polytechnic Institute», pp. 53-54. 
creation of a choreographic image by indirect and subordinated ideological and artistic content of a particular plot of copying folk dance ${ }^{7}$.

The alternative trend - representation of authentic Ukrainian folk dance without significant changes in the stage conditions, that's the author's interpretation of the original characteristics of folklore means of creation of a choreographic image by direct copying - was defended by V. Verkhovynets. However, in the early 30 s of the 20th century, this technique loses its relevance - the integration of Ukrainian folk dance into stage productions without theatrical adaptation and stylisation was unsuccessful for visual attractiveness for the audience ${ }^{8}$.

An innovative academic variety of Ukrainian staged folk dance as a result of complementing the sign system of folklore dance with abstractions of the classical choreography and enhancing expressiveness with unique plastic images to reveal the ideological and content aspect was developed and popularised by P. Virskyi.

A. Morozov ${ }^{9}$ emphasises that in P. Virskyi's understanding, a powerful means of enhancing the showmanship of stage production and theatrical adaptation of folk dance was virtuosity. For example, the use of rich virtuosic movements, acrobatic elements and stunt technique (in particular, dance with weapons) by the choreographer to demonstrate the unique physical training, strength, talent and dexterity of Ukrainian soldiers contributed to the intensification of dramatisation and disclosure of the theme of the Zaporozhian Cossacks in choreography. For example, in P. Virsky's production Zaporozhians, for the first time in stage choreography, more than 30 exercises with spears were used. It should be noted that in prestage forms of Ukrainian folk dance stunt elements were used only as a competitive element.

The mentality of the Ukrainian people is represented in traditional examples of national culture - concepts, myths, images, symbols. The

7 Doroshenko V. F. (2014) Rol khoreografa-postanovshchika P. P. Virskogo V protcesse vozniknoveniia i razvitiia narodno-stcenicheskogo khoreograficheskogo iskusstva Ukrainy [The role of the choreographer-director P. P. Virsky in the process of creation and development of folk-stage choreographic art of Ukraine]. Bulletin of Slavic Cultures, no. 2(32), pp. 171-180.

${ }^{8}$ Bilash P. M. (2004) Baletmeisterske mystetstvo i stanovlennia ukrainskoi stsenichnoi khoreohrafii u konteksti rozvytku yevropeiskoi khudozhnoi kultury 10-30-kh rokiv $X X$ stolittia [Choreography and the formation of Ukrainian stage choreography in the context of the development of European art culture of the 10-30 of the XX century] (Abstract of $\mathrm{PhD}$ Dissertation), Kyiv: State Academy of culture and arts management, p. 13.

9 Morozov A. I. (2019) Virtuoznist v ansambliakh narodnoho tantsiu Ukrainy radianskoi doby [Virtuosity in Ukraine's folk dance ensemblesof the Soviet era]. Dance studies, vol. 2, no. 2, p. 143. 
artistic and figurative content of staged folk dance reflects not only national images of the world but also labour and everyday traditions, peculiarities of the natural environment, rites, customs, beliefs, legends and myths. In particular, the tales of ancient Ukrainians have preserved the original sign and symbolic nature of early beliefs and cultural images of the people.

We emphasise the presence of characteristic features of theatricality directly in the folk dances of Ukrainians, especially those related to ritualism, which is full of song and dance folklore and dramatic action. For example, in the calendar ritualism of Ukrainians, the ritual origins of drama and the embodiment of various manifestations of theatricality inherent in Ukrainian folk dance can be traced: satire, imitation, reincarnation, grotesque, acting, the embodiment of specific images (Malanka, Spring, etc.), semantic content, artistic imagery, symbolism and figurative metaphoricality of choreographic language, etc. Over the centuries, the semantic aspect of Ukrainian folk dance has been imagery, imitation, which gradually acquired figurative and expressive and symbolic forms.

The stories of relationships between lovers unfold theatrically, which is expressed in the repeated change of the tempo of the musical accompaniment, and, accordingly, the change of mood, state of the characters and dramatic twists and turns. The compositional structure of some dances includes the semantic meaning - the external action is minimised, at the same time the internal, emotional and expressive one is enhanced, which, first of all, depends on the performing interpretation.

\section{Development Vector of Staged Folk Dance in the 21st Century}

During the first decades of the 21st century, several directions were observed in the development of Ukrainian staged folk dance:

- creation of innovative choreographic works, in which the directors intensify the process of synthesis of folklore and classical dance, strive to enrich and expand the lexical means of expression, vividly and unconventionally embody topics relevant to modern society through the use of specific - traditional and expressive and visual - expressive means of staged folk dance;

- use of standard techniques and compositional stamps in the process of lexical material presentation.

Both directions are marked by certain positive and negative trends. In particular, among the negative ones we can mention the strengthening of the separation of the author's staged folk choreography from folklore primary sources; excessive stylisation of expressive means, which instead of 
updating it, leads to the levelling of the originality of Ukrainian folk dance and Ukrainian staged folk choreography accordingly.

However, among positive ones, we can name the enhancing of the theatrical expressiveness of choreographic compositions due to the integration of plastic nuances into the lexical frame of dance. Only under the condition of preserving the canons of folklore dance, operating with various methods of Ukrainian folk dance interpretation by modern choreographers, the process of revival of traditions according to the artistic requirements of the 21 st century is realised.

The author's line of development of Ukrainian staged folk dance is distinguished by considerable freedom in the process of creative search, interpretation of folk dance elements, as well as the dominance of various methods of theatrical adaptation. According to the development of this direction, Ukrainian staged folk dance is characterised by increasing the amplitude of movements, the development and improvement of dance techniques, the variability of dynamics and tempo, the creation of innovative movements and their combinations. The lexical structure of jumping and other virtuosic movements of Ukrainian staged folk dance is not limited at the present stage, provided that the characteristic plastic and expressive features are maintained.

A huge number of national and original lexical systems of Ukrainian staged folk dance, a variety of expressive means, in general, provide great opportunities for modern national choreographers to create new choreographic productions, constant updating and enrichment of well-known staged folk compositions. Subject to the detailed research and deep understanding of the process of origin of national sacred images and symbols, their semantic, mythological and ritual basis, the transmission by means of Ukrainian staged folk dance takes place.

Ukrainian staged folk dance is characterised by the following principles of theatrical adaptation:

- drama and narrative nature of the production: according to the specifics of the sociocultural context, the most popular and effective format for representing Ukrainian folk dance on stage is the use of the context of calendar or family holidays (in particular, weddings), labour or daily activities (Lisoruby (Woodcutters), Bondar (Cooper), Kosari (Mowers), love stories, military motives (Arkan, Hopak, Zaporozhians, Opryshky, etc.), as well as visualisation of song lyrics;

- the dramaturgy of the construction of the dance story is clearly expressed: the developed picture of the dance reflects the conflict; the principle of opposition of tempo and rhythm, spatial dynamics is used; the direction to the climax, which is expressed in each dance episode, is clearly defined; 
- the organic interaction of choreographic dramaturgy with music;

- the development of stages of dance action on the principle of editing of separate episodes;

- the perfect mastering of the pose as a semantic mise en scène by the performers;

- the dynamics of emotional and sensory tension in choreographic production by means of symbolisation and metaphorisation;

- bright spectacular syncretism of dance action: local national colour is usually enhanced using scenery, costumes and props;

- the orientation of the spatial composition of the dance on the spectator; however, the geometric structure of the productions at the present stage is distinguished by the use of not only horizontal and diagonal lines, but also squares, circles and semicircles by the choreographers;

- genre diversity, the individuality of composition and choreographic text.

The direction of staged folk production is built according to the laws of theatrical performance:

- selection and determination of the production genre;

- dramatic and symbolic design of dance space, similar to the spatial compositions of classical choreography (refinement of forms, clarity and rationality of choreographic pattern, the symmetry of mise en scène, circular design with the semantic centre in the centre of the circle, geometric forms of placement of performers (square, triangular, diagonal, ornamental);

- focusing on the soloists;

- contrast of male and female plasticity;

- unexpected mood swings;

- the change of tempo and rhythm, the revelation of metaphoricity, imagery, the symbolism of dance pattern.

Thus, theatricality is the fundamental basis of Ukrainian staged folk choreography.

\section{CONCLUSIONS}

At the beginning of the 21st century, Ukrainian choreographic art in general and staged folk choreography, in particular, responds to the influence of civilisational processes, changes in historical and cultural models that are happening in the world. Dramatic and staged folk choreographic performance in the sociocultural space of Ukrainians of the 21 st century is transforming according to the understanding of various cultural and artistic world trends, getting theatrical and syncretic features. Theatrical adaptation violates the canons of Ukrainian folklore dance and enriches the choreography with innovative, expressive elements. 
At the present stage of development of Ukrainian folk choreographic art, the theatrical adaptation tendency occurs on several levels. This is primary and secondary theatrical adaptation. The primary theatrical adaptation is applied within the process of a folk dance production with maximum preservation of the specifics of the original source and the approach of the director, which can be described as an artistic understanding of reality. The secondary theatrical adaptation is shown in the process of creation of innovative choreographic expressiveness by integrating additional theatrical conventionality into the primary theatrical space of dance, which creates the effect of duality and expands the staging possibilities of interpretation of the folklore source significantly.

The prospects for further researches consist in a more detailed consideration of the principles of functioning of secondary theatrical adaptation in the Ukrainian staged folk dance of the 21st century and determination of its role in the general system of folk choreographic art of Ukraine.

\section{SUMMARY}

The purpose of the study is to identify the specifics of theatrical adaptation as a trend in the development of Ukrainian staged folk choreography in historical retrospect and at the present stage. Research methodology. The methodological basis of the research is the historical and cultural method (to study the features of the process of formation and development of professional national choreographic art), the cultural and typological method (to identify the essential characteristics and forms of staged folk dance), the method of artistic and aesthetic analysis (to analyse the artistic and symbolic nature of the expressiveness of stage works of folk choreography), the comparative method (to identify differences in the process of implementing the trend of theatrical adaptation in the late 19th early 20th century in the period of formation of national professional choreography and at the present stage). Scientific novelty. The key features of the phenomenon of theatrical adaptation in the context of the specifics of the development of Ukrainian staged folk choreographic art are identified and considered as a unique type of artistic worldview. Conclusions. At the beginning of the 21 st century, Ukrainian choreographic art in general and staged folk choreography, in particular, responds to the influence of civilisational processes, changes in historical and cultural models that are happening in the world. Dramatic and staged folk choreographic performance in the sociocultural space of Ukrainians of the 21st century is undergoing transformations according to the understanding of various cultural and artistic world trends, getting theatrical and syncretic features. 
Theatrical adaptation violates the canons of Ukrainian folklore dance and enriches the choreography with innovative, expressive elements.

At the present stage of development of Ukrainian folk choreographic art, the theatrical adaptation tendency occurs on several levels. This is primary and secondary theatrical adaptation. The primary theatrical adaptation is applied within the process of a folk dance production with maximum preservation of the specifics of the original source and the approach of the director, which can be described as an artistic understanding of reality. The secondary theatrical adaptation is shown in the process of creation of innovative choreographic expressiveness by integrating additional theatrical conventionality into the primary dramatic space of dance, which creates the effect of duality and expands the staging possibilities of interpretation of the folklore source significantly.

\section{REFERENCES}

1. Bilash P. M. (2004) Baletmeisterske mystetstvo i stanovlennia ukrainskoi stsenichnoi khoreohrafii u konteksti rozvytku yevropeiskoi khudozhnoi kultury 10-30-kh rokiv XX stolittia [Choreography and the formation of Ukrainian stage choreography in the context of the development of European art culture of the 10-30 of the XX century] (Abstract of PhD Dissertation), Kyiv: State Academy of culture and arts management.

2. Doroshenko V. F. (2014) Rol khoreografa-postanovshchika P. P. Virskogo v protcesse vozniknoveniia i razvitiia narodnostcenicheskogo khoreograficheskogo iskusstva Ukrainy [The role of the choreographer-director P. P. Virsky in the process of creation and development of folk-stage choreographic art of Ukraine]. Bulletin of Slavic Cultures, no. 2(32), pp. 171-180.

3. Hutnyk I. M. (2019) Stylizatsiia u profesiinomu narodnomu khoreohrafichnomu mystetstvi suchasnosti [Styling in professional folk choreographic art of the present]. National Academy of Managerial Staff of Culture and Arts Herald, no. 2, pp. 356-360.

4. Khotsianovska L. F. (2018) Tendentsii ta perspektyvy rozvytku narodnoho khoreohrafichnoho mystetstva Ukrainy [Trends and prospects of the development of folk choreographic art of Ukraine]. Young Scientist, no. 1(53), pp. 191-194.

5. Morozov A. I. (2019) Virtuoznist v ansambliakh narodnoho tantsiu Ukrainy radianskoi doby [Virtuosity in Ukraine's folk dance ensemblesof the Soviet era]. Dance studies, vol. 2, no. 2, pp. 137-148.

6. Nechytailo V. S. (2017) Narodne khoreohrafichne mystetstvo Ukrainy u sotsiokulturnykh umovakh sohodennia [Folk choreographic art of 
Ukraine in the modern socio-cultural condition]. National Academy of Managerial Staff of Culture and Arts Herald, no. 2, pp. 88-93.

7. Protopapadakis E., Grammatikopoulou A., Doulamis A., Grammalidis N. (2017) Folk Dance Pattern Recognition over Depth Images Acquired via Kinect Sensor. The International Archives of the Photogrammetry, Remote Sensing and Spatial Information Sciences, vol. XLII-2/W3, pp. 587-593. https://doi.org/10.5194/isprs-archives-XLII-2W3-587-2017

8. Shlemko O. (2002) Arkhaichni narodni tradytsii v interpretatsii Hutsulskoho teatru Hnata Khotkevycha [Archaic folk traditions in the interpretation of the Hutsul Hnat Khotkevych Theater]. Proceedings of the Tradytsiia i suchasne v ukrainskii kulturi: Mizhnarodna naukovo-praktychna konferentsiia (Ukraine, Kharkiv, December 18-21, 2002). Kharkiv: National Technical University «Kharkiv Polytechnic Institute», pp. 53-54.

9. Vasylenko K. Yu. (1996) Leksyka ukrainskoho narodnostsenichnoho tantsiu [Vocabulary of Ukrainian folk stage dance]. Kyiv: Mystetstvo. (in Ukrainian)

Information about the author: Boiko Olha orcid.org/0000-0001-4534-2201 $\mathrm{PhD}$ in Art Studies, Associate Professor Kyiv National University of Culture and Arts 36, Ye. Konovaltsia Str., Kyiv, 01133, Ukraine 